\title{
Variation in the volume of lubricating eyedrops available in the brazilian market
}

\author{
Variação do volume de gotas de colírios \\ lubrificantes disponíveis no mercado brasileiro
}

Vitorugo Silvestre Nascimento1, Priscila Cardoso Cristovam², Joyce Luciana Covre², José Álvaro Pereira Gomes², Denise de Freitas², Vagner Rogério dos Santos ${ }^{2,3}$

\begin{abstract}
Objective: To evaluate the intra and inter variations of eye drops volume dispensed from bottles available on the market. Methods: Five bottles of lubricant eye drops were studied and nineteen volunteers participated in this study. The average mass from $20 \mu \mathrm{l}$ of eye drops was obtained using accuracy micropipette and balance, and used as standard for comparison with the mass of the drops obtained by the volunteers. Five drops of each vial were individually weighed with the tube perpendicular to the balance, using the first and second fingers of the right hand, so that the pressure was applied only in the middle of the flask. The experiments were performed in a room temperature $\left(21 \pm 1^{\circ} \mathrm{C}\right)$. Results: All eye drops bottles showed a statistically significant variation on masses of the drops obtained by examiners when compared with the standard average weight of $0.0182 \pm 0,0014 \mathrm{~g}$, except when compared $A$ with D eye drops, with no statistically significant variation. Conclusion: This study demonstrates the lack of uniformity of drops dispensed by eye drops bottles available in the market and its inadequacy to the real need, since the dispensed drops are larger than indicated. This fact becomes a problem when it comes to long treatment period, especially with expensive drops as indicated for glaucoma therapy. In this sense, the standardization of drops of eye drops is necessary.
\end{abstract}

Keywords: Lubrificant eye drop/administration \& dosage; Ophtalmic solutions/administration \& dosage; Instillation, drug

\section{RESUMO}

Objetivo: Avaliar a variação intra e interexaminadores do volume de gotas dispensados de frascos de colírios lubrificantes disponíveis no mercado. Métodos: Foram estudados cinco frascos de colírios lubrificantes e dezenove voluntários participaram deste estudo. A massa média de gotas de $20 \mu \mathrm{l}$ dos colírios foi obtida utilizando micropipeta e balança de precisão e como padrão para comparação com a massa das gotas obtidas pelos voluntários. Cinco gotas de cada frasco foram pesadas individualmente com o tubo de colírio perpendicular à balança, usando o primeiro e segundo dedos da mão direita, de forma que a pressão fosse aplicada somente no meio do frasco. Os experimentos foram realizados em uma sala climatizada a temperatura ambiente $\left(21 \pm 1^{\circ} \mathrm{C}\right)$. Resultados: Todos os frascos de colírios apresentaram variação estatisticamente significante das massas das gotas obtidas pelos examinadores quando comparadas com a massa média padrão de $0,0182 \pm 0,0014 \mathrm{~g}$, com exceção da comparação entre os dados do colírio A com o colírio D, que não apresentou variação estatisticamente significante. Conclusão: O presente estudo demonstra a ausência de uniformidade das gotas dispensadas pelos frascos de colírios disponíveis no mercado e a sua inadequação à real necessidade, uma vez que as gotas dispensadas são maiores do que o indicado. Esse fato torna-se um problema quando se trata de período de tratamento prolongado, especialmente com colírios dispendiosos como os indicados para a terapêutica do glaucoma. Nesse sentido, a padronização das gotas de colírios se faz necessária.

Descritores: Lubrificantes oftálmicos/administração \& dosagem; Soluções oftálmicas/administração \& dosagem; Instilação de medicamentos

1, 2, 3 Universidade Federal de São Paulo, São Paulo, SP, Brazil.

The authors declare no conflicts of interests.

Received for publication 09/05/2016 - Accepted for publication 23/11/2016. 


\section{INTRODUCTION}

I nstillation of aqueous solutions in the lower conjunctival sac is the most used form of administration of drugs to treat diseases of sight, since the application is easy and well tolerated when done correctly. ${ }^{(1-3)}$ The instilled volume strongly determines the therapeutic action of the drug, and can lead to adverse effects due to systemic absorption. The study of Kumar et al. (2011)(4), showed that a volume around 20il is ideal for ophthalmologic treatment, and drops above 25iL cause drug wastage because the tear film does not support volumes greater than $20 \mu \mathrm{L} .^{(1,4)}$

Excess volume of the drops in the installation associated with lack of guidance for correct use of eyedrops increases the possibility of systemic absorption and the risk of unwanted adverse effects. The blink reflex due to a higher volume of drops applied increases by up to four times the flow of the drug drained by the tear duct, which promotes greater systemic absorption and, at the same time, stimulates tearing and decreases the amount of drug absorbed in the anterior chamber. ${ }^{(1,5-7)}$ Most ophthalmic solutions are currently available in bottles of 5,10 or 15 milliliters $(\mathrm{ml})$, and they dispense drops with volumes ranging from 25 to $70 \mathrm{iL}$ (average of 40iL). $(2,4,8)$

The volume of drops dispensed from a bottle of eyedrops depends on several factors, among which: A) The physicochemical properties of the solution (surface tension, viscosity and density) $)^{(4,}$ $5,9,10)$; B) The design of the bottle along with its geometry, the material with which the bottle is manufactured, its stiffness (resistance to the force applied), and in particular the diameter of the external orifice of the eyedropper nozzle, which are important to determine the volume of the drops dispensed. (Figura 1) ${ }^{(3,5,9)}$; C) The strength made during instillation, the handling of the eyedrops bottle by the patient, how fast the drop is formed, and the position of the bottle in relation to the ocular surface are also factors to influence the final volume of the drop formed.$^{(5,6,11)}$

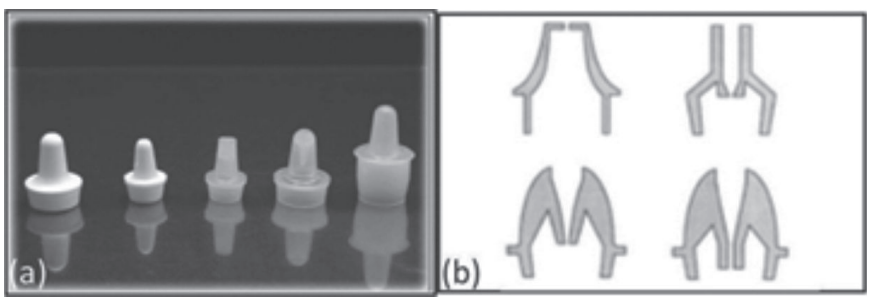

Figure 1: Illustrative picture of different types of eyedropper nozzles. Different types of eyedropper nozzles (A); and cross sections, inner diameter and shape of the external hole (B).

Source: Adapted from Van Santvliet L, Ludwig A. Determinants of eye drop size. Surv Ophthalmol. 2004;49(2):197-213. ${ }^{(4)}$

The lack of uniformity in the volume of drops dispensed from the bottles of eyedrops is a reason for attention due to waste, especially when it comes to expensive eye drops like those used to treat glaucoma patients. ${ }^{(12)}$

The rising cost of health care has become a concern. In ophthalmology, glaucoma, for example, has a significant financial impact for the public health system, since it requires the chronic use of medications, surgical procedures, consultations and frequent complementary exams. In addition, there are indirect costs, such as the expenses with the caregiver for the visually impaired and with rehabilitation, disability to work, among others. ${ }^{(13)}$

The objective of this study was to evaluate the intra and inter - examiner variation of the volume of drops dispensed from the bottles of lubricating eyedrops (artificial tears) from five manufacturers available in the Brazilian market.

\section{MethodS}

\section{Experimental design}

This study was approved by the Research Ethics Committee of Universidade Federal de São Paulo-UNIFESP, under CEP No.: 1092211014. The metrological procedure was performed in a room heated to room temperature of $21^{\circ} \mathrm{C} \pm 1^{\circ} \mathrm{C}$ to avoid fluctuations that could interfere with the measurements obtained. Nineteen healthy volunteers (examiners) aged between 18 and 57 years (average of $30 \pm 12$ years) participated in this study. The criteria for inclusion of volunteers in the study were:

I. People with full physical capacity, i.e., without any neuromotor dysfunction that could be a bias for the experiment;

II. People without cognitive impairments that could affect the understanding of the test to be carried out;

For validation of the method, we used five different lubricating eyedrops (artificial tears) purchased in local drugstores. The choice for this type of eyedrops was based on the cost and easy access to the drugs, and the brand name and the active drug principle were randomized, with the concentration and density of the solutions not taken into account in the analyzes. For better organization of data, the eyedrops were randomly called eyedrops A, B, C, D and E.

\section{Trial}

The tests to obtain the mass of drops obtained from the bottles of lubricating eyedrops were performed on a precision balance (Bioprecisa Electronic Balance FA2104N - Bioprecisa, Curitiba - PR) with a resolution of $10^{-4} \mathrm{~g}$ (Figure 2a) for subsequent correlation with the volume, by comparing the mass and volume dispensed by a calibrated pipette (Eppendorf Research - Hamburg, Germany) (Figure 2b). The experiment protocol was established so that volunteers could apply a pressure with the first and second fingers on the side walls of the tube positioned perpendicularly to the scale, as shown in Figure 3. Each volunteer dispensed five drops of each eyedrop for a total of twenty five drops per volunteer.

\section{Determination of the standard average mass}

In order to correlate the mass values of the drops of the eyedrops obtained with the volume in microliters, 20il $\pm 0.02 \mathrm{il}$ were obtained with the aid of a micropipette calibrated by a single examiner, five times of each vial of eyedrops, and the mean mass obtained was used as standard (reference) to correlate mass $\mathrm{x}$ volume. Table 1 shows the concentration and composition of the active principle of each eyedrop (package insert). 


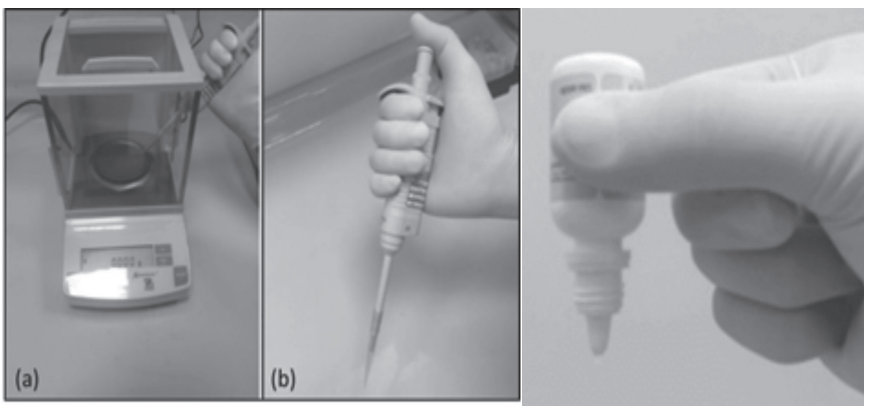

Figure 2: Model of apprehension of the bottle of eye drops in the form of "tweezers"

Table 1

Composition of the active ingredient of the eyedrops

\begin{tabular}{cl}
\hline Eyedrop & \multicolumn{1}{c}{ Composition of the active ingredient } \\
\hline A & Hypromellose $3.2 \mathrm{mg} / \mathrm{ml}$ \\
B & Carboxymethylcellulose Sodium $5 \mathrm{mg} / \mathrm{ml}$ \\
C & Dextran $70.1 \mathrm{mg} / \mathrm{ml}$, Hypromellose $3 \mathrm{mg} / \mathrm{ml}$ \\
D & Carboxymethylcellulose Sodium $5 \mathrm{mg} / \mathrm{ml}$ \\
E & Dextran $1.0 \mathrm{mg}$, Hypromellose $3.0 \mathrm{mg} / \mathrm{ml}$ \\
\hline
\end{tabular}

\section{Statistical analysis}

The data obtained were evaluated by analysis of simple variance (One-way ANOVA) using the software SigmaStat (Systat Software - San Jose, California). The comparisons were made inter- and intra-examiners, and the results were considered statistically significant when $\mathrm{p}$ value $<0.05$.

\section{ResULTS}

To establish a mass standard as a function of volume, 5 drops of $20 \pm 0.02 \mathrm{il}$ were obtained with a micropipettor by a single examiner from each of the eyedrop bottles and then weighed one at a time on a precision balance. The values obtained are arranged in table 2, and its distribution can be best viewed in Figure 4. For a volume of 20il, the average mass of all eye drops was equivalent to $0.0182 \pm 0.003 \mathrm{~g}$.

Table 2

Standard average mass of eyedrops (g)

\begin{tabular}{cccccc}
\hline Measure & Eyedrop A & Eyedrop B & Eyedrop C & Eyedrop D & Eyedrop E \\
\hline 1 & 0,0187 & 0,0191 & 0,0162 & 0,0185 & 0,0170 \\
2 & 0,0188 & 0,0192 & 0,0165 & 0,0201 & 0,0170 \\
3 & 0,0185 & 0,0196 & 0,0163 & 0,0202 & 0,0172 \\
4 & 0,0181 & 0,0196 & 0,0165 & 0,0197 & 0,0171 \\
5 & 0,0185 & 0,0196 & 0,0168 & 0,0202 & 0,0169 \\
\hline Average & 0,0185 & 0,0194 & 0,0165 & 0,0197 & 0,0170 \\
\hline SD & 0,0003 & 0,0002 & 0,0002 & 0,0007 & 0,0001 \\
\hline
\end{tabular}

Individual values, average and standard deviation (SD) of the mass (in grams) obtained from 201 l of eyedrops for determination of the standard average mass of eyedrops. .
Graph 1

Determination of the standard average mass

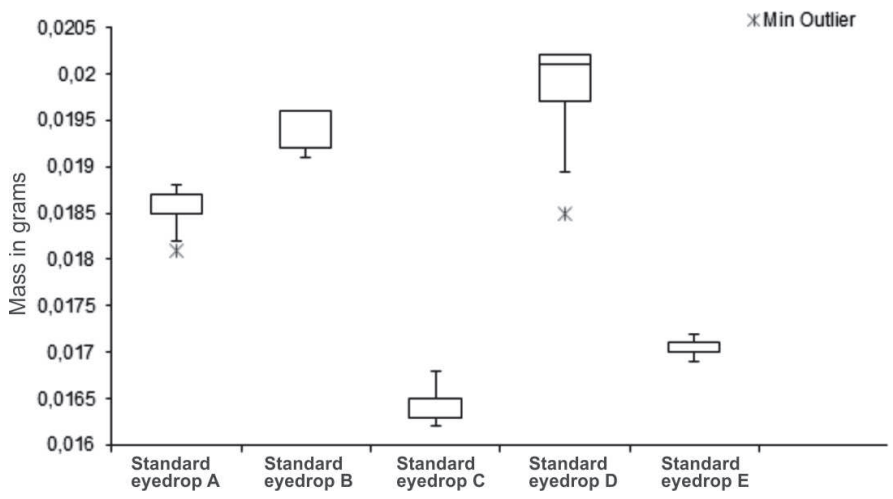

Boxplot showing the distribution of mass of drops of $20 \pm 0.02$ il of each eyedrops. The overall average of the standards was $0.00182 \pm$ $0.0014 \mathrm{~g}$; this value was used as a reference mass $\mathrm{x}$ volume to correlate with the masses of the eyedrops obtained by the volunteers.

Table 3 shows data relating to measurements made by the volunteers. The values obtained from the masses of different eyedrops did not show statistically significant variation when compared among the volunteers $(\mathrm{p}>0.05)$.

Table 3

Average of masses of the different eyedrops

\begin{tabular}{ccc}
\hline Eyedrop & Mass $(\mathbf{g})(\mathbf{x} \pm \mathbf{S D})$ & p-Value \\
\hline A & $0.0355 \pm 0.0037$ & 0.221 \\
B & $0.0400 \pm 0.0039$ & 0.265 \\
C & $0.0314 \pm 0.0036$ & 0.265 \\
D & $0.0366 \pm 0.0040$ & 0.265 \\
E & $0.0499 \pm 0.0092$ & 0.265 \\
\hline
\end{tabular}

Mean, standard deviation (SD) and P-value of drops of eyedrops A, B, C, D and E obtained by volunteers $(n=19)$.

Graphs 2 to 7 shows the distribution of the masses obtained from the drops of eyedrops compared to the standard average mass in graph 1 . All eyedrops showed statistically significant variation $(\mathrm{p}<0.001)$ when compared to the standard of 20il, as well as when compared to each other (except when comparing data from eyedrop D to eyedrop A).

\section{Graph 2}

\section{Masses $(\mathrm{g}$ ) of the drops from different eyedrops}

Masses (in grams) of drops of each eyedrop obtained by 19 volunteers, and standard average mass obtained from $20 \mu \mathrm{l}$.

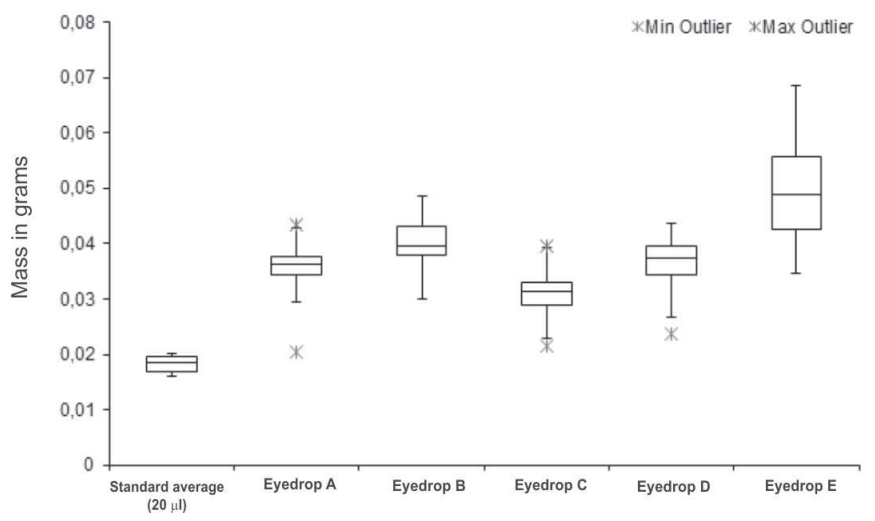




\section{Graph 3}

Dispersion of mass measures of Eyedrop A

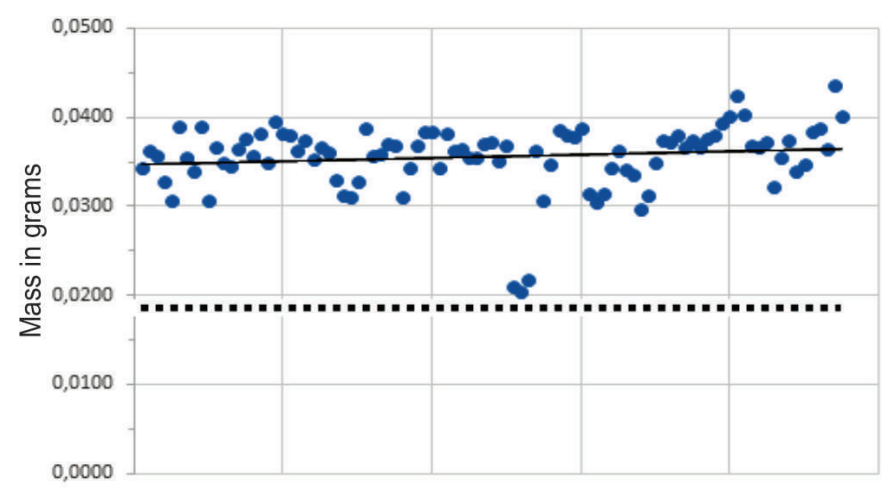

Eyedrop A. Dispersion of mass measures obtained by volunteers and trend line of the sample. The dashed line shows the standard mass obtained for the drops of $20 \mathrm{il}$ (Standard eyedrop A). The smallest value for mass obtained was $0.0205 \pm 0.0001 \mathrm{~g}$, and the greatest value was $0.0435 \pm 0.0001 \mathrm{~g}$ with an average of $0.0185 \pm 0.0003 \mathrm{~g}$.

\section{Graph 4}

\section{Dispersion of mass measures of Eyedrop B}

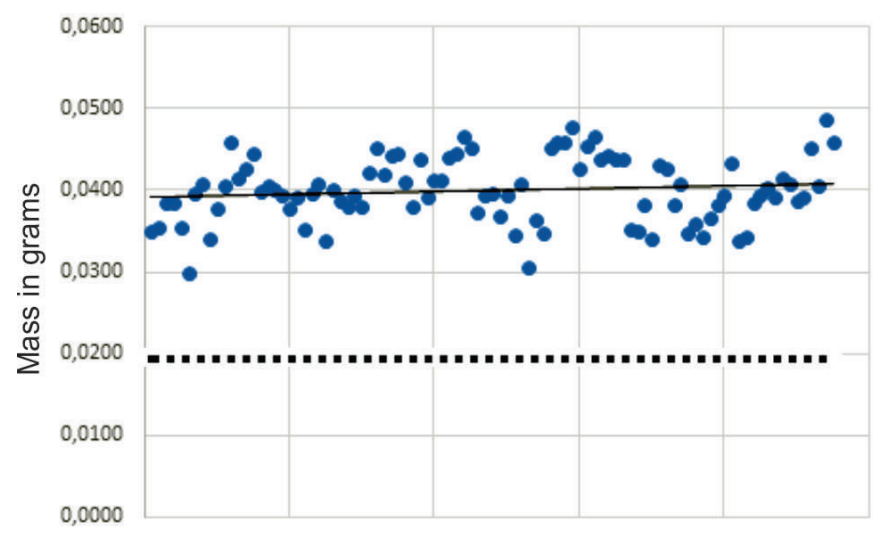

Eyedrop B. Dispersion of mass measures obtained by volunteers and trend line of the sample. The dashed line shows the standard mass obtained for the drops of $20 \mathrm{il}$ (Standard eyedrop B). The smallest value for mass obtained was $0.0300 \pm 0.0001 \mathrm{~g}$, and the greatest value was $0.0459 \pm 0.0001 \mathrm{~g}$ with an average of $0.0194 \pm 0.0002 \mathrm{~g}$.

\section{Graph 5}

\section{Dispersion of mass measures of Eyedrop C}

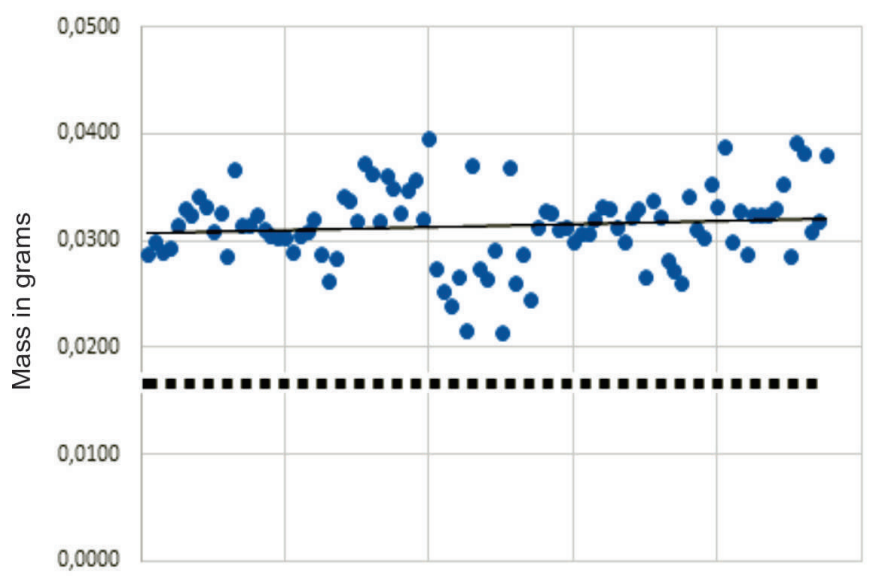

Eyedrop C. Dispersion of mass measures obtained by volunteers and trend line of the sample. The dashed line shows the standard mass obtained for the drops of 20il (Standard eyedrop C). The smallest value for mass obtained was $0.0215 \pm 0.0001 \mathrm{~g}$, and the greatest value was $0.0396 \pm 0.0001 \mathrm{~g}$ with an average of $0.0165 \pm 0.0002 \mathrm{~g}$.

\section{Graph 6 \\ Dispersion of mass measures of Eyedrop D}

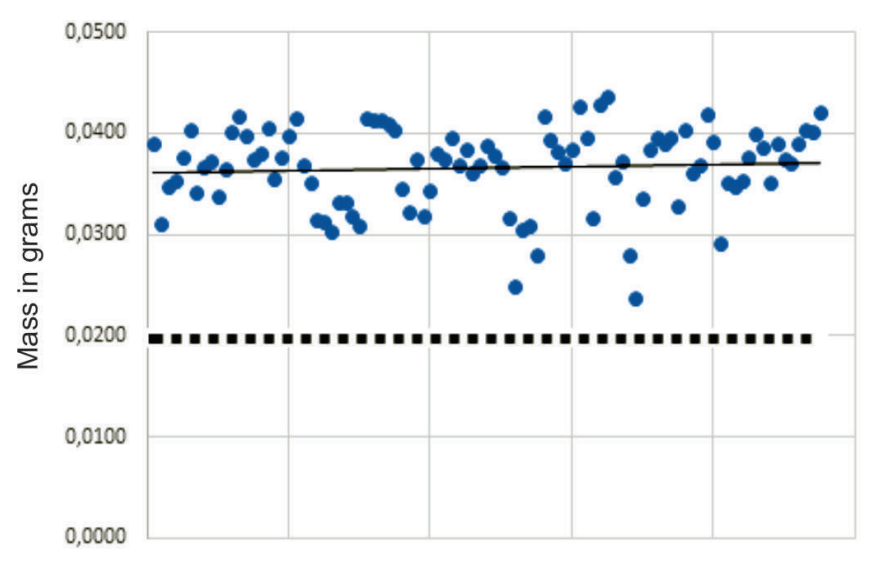

Eyedrop D. Dispersion of mass measures obtained by volunteers and trend line of the sample. The dashed line shows the standard mass obtained for the drops of 20il (Standard eyedrop D). The smallest value for mass obtained was $0.0237 \pm 0.0001 \mathrm{~g}$, and the greatest value was $0.0436 \pm 0.0001 \mathrm{~g}$ with an average of $0.0197 \pm 0.0007 \mathrm{~g}$.

\section{Graph 7 \\ Dispersion of mass measures of Eyedrop $E$}

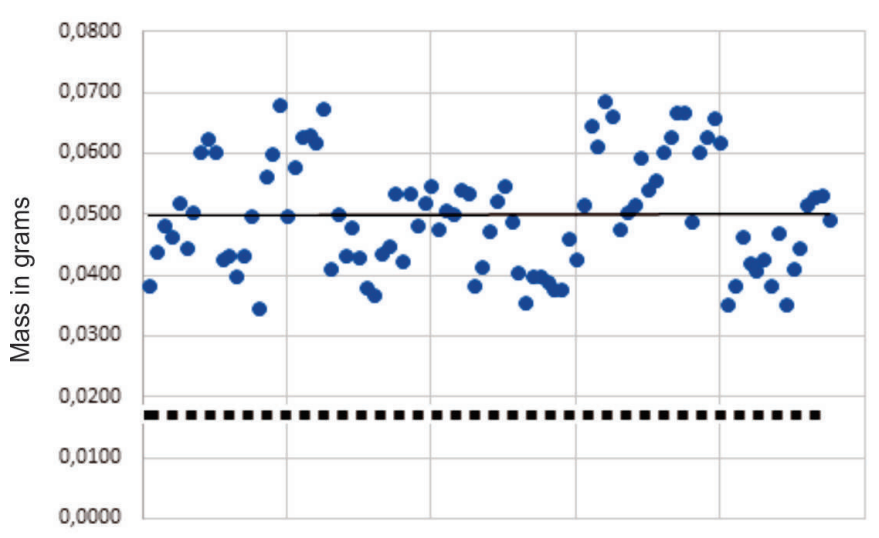

Eyedrop E. Dispersion of mass measures obtained by volunteers and trend line of the sample. The dashed line shows the standard mass obtained for the drops of 20il (Standard eyedrop E). The smallest value for mass obtained was $0.0347 \pm 0.0001 \mathrm{~g}$, and the greatest value was $0.0685 \pm 0.0001 \mathrm{~g}$ with an average of $0.0170 \pm 0.0001 \mathrm{~g}$.

\section{Discussion}

The lack of standardization of droplet volume of eyedrops is a problem the size of which can be better understood when treating dry eye syndrome, a multifactorial disease that affects the tear film and consequently the ocular surface as a whole in approximately 15 to $20 \%$ of the world population. 
Another pathological condition which also requires longterm topical treatment is glaucoma, a degenerative disease of the optic nerve that has high prevalence and is considered one of the most important causes of blindness. If the patient does not proceed with the application of eyedrops, the increase of intraocular pressure can lead to a degenerative process of the optic nerve that, most likely, will cause an irreversible blindness. The social and economic damages (high social security costs) caused by these events make the standardization of the volume of the drop a public health problem.

In the present study, the lubricating eyedrops were chosen according to the price, being selected those that were cheaper in the drugstores. The data presented in graph 1 show that, for a standard volume of 20il obtained by means of a calibrated micropipette, there was a variation in the droplet masses of the eyedrops measured on the precision balance, which indicates a discrepancy in the density of the inter-manufacturers solutions, which is an important factor in the formation of the drop. The variability of the mass of the drops of the different eyedrops can be explained by the difference between the composition of the active principle of the same observed in table 1 . However, it is important to note that the mass data of the drops obtained by the nineteen volunteers were compared to the standard mean mass of 20 il of each eyedrop, which presented statistically significant variation.

Graph 2 shows that in the tests performed by the volunteers there was an absence of uniformity in the masses dispensed from the bottles when comparing the eyedrops among themselves ( $p<0.001)$. However, this statistically significant variation did not occur when comparing eyedrops A and D. When analyzing the boxplot graph of each eyedrop individually, a large amplitude can be seen in the mass measurements obtained, and eyedrop E presented the greatest one. This lack of uniformity can also be verified when we make an intravoluntary analysis in each eyedrop. Graphs 3, 4, 5, 6 and 7 show the dispersion of all the measurements obtained, their trend lines and the comparison with the standard mass of $0.0182 \mathrm{~g}$ (corresponding to 20il) in the dashed line. The largest average mass was in eyedrop D (0.0197 $\pm 0,0007 \mathrm{~g})$, and the lowest was in eyedrop C $(0.0165 \pm 0.0002 \mathrm{~g})$. In the mass $\mathrm{x}$ volume comparison, which could be made due to standard mass measurements of $0.0182 \mathrm{~g}$ corresponding to a $20 \mathrm{il}$ drop, the mean volume of drops measured was 43ìl, which indicates that the mean volume per drop is approximately $215 \%$ higher than that recommended in the literature (20 il).

The differences observed in the measures of eyedrops corroborate with other studies that may be due to several factors, isolated or together, among them the variation in the strength used in instillation (different volunteers use different strengths in the application), the variation in the densities of the solutions since the eyedrops are from different manufacturers, the viscosity of the solutions and the nature of the drug. ${ }^{(1,3,5)}$

As described by the American and European Pharmacopoeia, the size of the droplet volume should be 40il and the Ministry of Health recommends that the volume of droplets should be less than 50il (8). However, the data obtained in this study are in agreement With current standards. However, the literature $\mathrm{e}^{(1,3,5)}$ indicates that the maximum volume indicated so that the therapeutic action of the drug is effective and with no drug wastage is 20il, and larger volumes may increase the systemic absorption of the drug causing side effects or leaking out of the eye, thus wasting eyedrops, both of which are undesirable consequences. From a toxicological point of view, even smaller drops should be instilled from 5 to $15 \mathrm{l}$ per drop. ${ }^{(1,3,14)}$ There are on the market some vials of lubricating eyedrops with more modern release systems (eyedropper nozzle), with a technology that does not use preservatives because the packages prevent the entrance of air and they release only the exact dose of eyedrops at each application. Thus, we will avoid an overdose, contamination and waste of artificial tears. These new eyedrops have not been tested in the present study.

The data obtained in this study indicate the absence of uniformity in the drop volume obtained from the eyedrops tested. This fact becomes a serious problem when analyzing the costs of treatment for the diseases of the vision that go far beyond the price of the medicine, as they include medical care, caregivers for those already affected by blindness, social security expenditures due to disability, etc. In this sense, the standardization of the volume is necessary.

\section{ReFERENCES}

1. Souza S, Aguiar P, Lyra Jr D, Silva W. Avaliação da aplicação da técnica de administração de colírios por pacientes idosos de um centro de especialidades médicas. Rev Ciênc Farm Básica Apl. 2014;35(4):671-7.

2. Sklubalova Z, Zatloukal Z. Systematic study of factors affecting eye drop size and dosing variability. Pharmazie. 2005;60(12):917-21.

3. Van Santvliet L, Ludwig A. Determinants of eye drop size. Surv Ophthalmol. 2004;49(2):197-213.

4. Kumar S, Karki R, Meena M, Prakash T, Rajeswari T, Goli D. Reduction in drop size of ophthalmic topical drop preparations and the impact of treatment. J Adv Pharm Technol Res. 2011;2(3):192-4.

5. German EJ, Hurst MA, Wood D. Reliability of drop size from multidose eye drop bottles: is it cause for concern? Eye (London). 1999;13(1):93-100.

6. Fiscella R, Wilensky JT, Chiang TH, Walt JG. Efficiency of instillation methods for prostaglandin medications. J Ocul Pharmacol Ther. 2006;22(6):477-82.

7. Fraunfelder FT, Meyer SM. Systemic adverse reactions to glaucoma medications. Int Ophthalmol Clin. 1989;29(3):143-6.

8. Estacia P, Tognon T. Considerações sobre o ângulo de administração de colírios antiglaucomatosos análogos das prostaglandinas. Arq Bras Oftalmol. 2008;71(5):684-8.

9. Yoshikawa K, Yamada H. Influence of container structures and content solutions on dispensing time of ophthalmic solutions. Clin Ophthalmol. 2010;4:481-6.

10. Van Santvliet L, Ludwig A. Influence of the physico-chemical properties of ophthalmic viscolysers on the weight of drops dispensed from a flexible dropper bottle. Eur J Pharm Sci. 1999;7(4):339-45.

11. Gaynes BI, Singa RM, Schaab G, Sorokin Y. Impact of administration angle on the cost of artificial tear solutions: does bottle positioning minimize wastage? J Ocul Pharmacol Ther. 2007;23(2):196-201.

12. Rylander NR, Vold SD. Cost analysis of glaucoma medications. Am J Ophthalmol. 2008;145(1):106-13.

13. Guedes RA, Guedes VM, Chaoubah A. Custo-efetividade dos análogos de prostaglandinas no Brasil. Rev Bras Oftalmol. 2008;67(6):281-6.

14. Costa AX, Gama RM, Kitadai SP , Andrade EP , Ferro GB , Gomes JÁ. Volume da gota dos colírios lubrificantes: estudo farmacoeconômico. Rev Bras Oftalmol. 2015;74(6):339-44.

\section{Corresponding author:}

Vagner Rogério dos Santos

Rua Noel José da Silva, 170 Vila São Francisco, Penha, SP.

ZIP Code 03678030

Fax: (11) 5082-3588

E-mail: vagner_rogerio@yahoo.com.br 